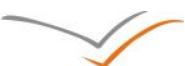

\title{
VERSITA
}

\section{Selection Process of ERP Systems}

\section{Bálint Molnár}

Eötvös University of Budapest, Faculty of Informatics, Information Systems Department, Budapest, Hungary

\section{Gyula Szabó}

Dénes Gábor University of Applied Sciences, Budapest, Hungary

\section{András Benczúr}

Eötvös University of Budapest, Faculty of Informatics, Information Systems Department, Budapest, Hungary

\begin{abstract}
Background: The application and introduction of ERP systems have become a central issue for management and operation of enterprises. The competition on market enforces the improvement and optimization of business processes of enterprises to increase their efficiency, effectiveness, and to manage better the resources outside the company. The primary task of ERP systems is to achieve the before-mentioned objectives. Objective: The selection of a particular ERP system has a decisive effect on the future operation and profitability of the enterprise. The qualitative correlation between the size of enterprises, market position, etc. and the applied selection criteria for ERP systems should be analysed as to whether which criteria are used at multinational enterprises or at SMEs. Methods/Approach: Our research is grounded in a literature review and case studies of everyday practice related to the introduction, implementation and roll-out of ERP systems. Results: The dominant critical success factor of ERP introduction seems to be "ERP software suitability", "Information quality", "ERP vendor quality". Conclusion: The set of criteria on one hand shows strong correlation with non-functional requirements codified in standards, and on the other hand with usual functional requirements for ERP systems.
\end{abstract}

Keywords: Information System, ERP, Enterprise Resource Planning, Enterprise Architecture, Selection Criteria.

JEL classification: $M, M 1, M 15$

Paper type: Research article

Received: 20, July, 2012

Revised: 27, November, 2012

Accepted: 1, March, 2013

Citation: Molnár, B., Szabó, Gy., Benczúr, A. (2013). "Selection Process of ERP Systems", Business Systems Research, Vol. 4, No.1, pp. 36-48.

DOI: 10.2478/bsri-2013-0004

Acknowledgements: The Project is supported by the European Union and co-financed by the European Social Fund (grant agreement no. TÁMOP-4.2.2/B-10/1-2010-0030).

\section{Introduction}

To highlight the recent tendencies in an economic crisis, we have investigated the trends in two EU member countries (Hungary and Germany) empirically and by publications related to business management and economics. The research goal was to discover the most recent trend in the applied method of selection processes and the related set of criteria in practice, and a qualitative analysis about the impact and frequency of use in practice. We have studied concrete examples, cases of ERP selection and introduction. The source and empirical material of research consisted of in-depth interviews carried out by the research 
team, case studies description and elaboration performed by students, and publications appeared in scholarly periodicals, technical and business journals.

The research has collected primary criteria, requirements against ERP systems out of the scientific, technical and business literature. Using the set of criteria the case studies were analysed. Because of the size of the sample, the research intended to create a qualitative result as if which criteria, business and technical analysis methods were used in practice. To document and organize the results of research we concluded some tables that can be analysed by basic statistical methods to reveal some tendencies.

The organization of the paper: $\S 2$ provides a literature overview about ERP related issues as selection criteria and introduction. $\S 3$ describes the applied methodology of the research. In $\S 4$ we discuss case studies related to the selection process of ERP systems in Hungarian and German companies. $\S 5$ discusses and concludes the result of research. $\S 6$ overviews of related works, $\S 7$ summarizes this paper and $\S 8$ provides a brief overview about the planned future work.

\section{Literature review}

There are several, concurrent definition and circumscription for ERP that we have investigated in a previous article (Molnár 2011). In the scientific and technical literature, the concept of ERP is widely discussed as the environment of technology rapidly changes as new architecture appears e.g. SOA, Cloud Computing etc. (Siegel and Shim 2005), (Yen and Chang 2002), (Bidgoli and Hossein, 2004), (Lassmann 2006), (Jacobs and Whybark 2000). A thorough bibliography and short discussions on literature of ERP systems can be found in (Esteves and Bohórquez 2007), (Botta-Genoulaz, Millet and Grabot 2005), (Jacobs and Weston 2007), (Nazemi, Tarokh, and Djavanshir 2012).

The ERP system should cover the requirements of companies in various industrial sectors (Feuchtinger 2008). There are ERP systems that are dedicated to large and medium sized enterprises, to particular sectors as e.g. commerce or to companies having business functions overarching from manufacturing to sales and delivery (Eggert and Fohrholz 2009). We conclude that there are still individually developing systems beside standard systems within the industrial sector specific solutions.

As there are several definitions or circumscription of ERP systems as an information system in the literature we use the following definition attempt: organization-wide socio-technology, information system that provides information system services for the major business functions, namely human resource management, logistics in comprehensive term, i.e. including from sales and delivery to the production and its planning. The success or failure of implementing ERP systems is widely discussed in several publications (Ifinedo, Rapp, Ifinedo, and Sundberg 2010).

There are a lot of ERP alternatives in the market (Wei and Wang 2004). The failure in selection of ERP system firstly leads to the failure of ERP introduction or an adaptation project or secondly to degradation of company performance (Liao, Li, and Lu 2007). The literature contains several viewpoints concerning what variables are required for implementation success or responsible for failure (Umble et al. 2003), (Asl, Khalilzadehb, Youshanlovei, and Moodd 2012).

An ERP system is a social-technological system so that there are competing measurement approaches and concepts coming from research literature and practice. Some factors that can be encountered in the literature:

1. User satisfaction (Al-Mashari, Al-Mudimigh, and Zairi, 2003; Mandal et al. 2002), (Ang et al. 1995; Yusuf et al. 2004).

2. Intended business performance improvements (Al-Mashari et al. 2003; Hong and Kim 2002; Mandalet al. 2002; Markus et al., 2000; Yusuf et al. 2004).

3. On time (Al-Mashari et al. 2003; Hong et al. 2002; Malbert et al. 2003).

4. Within budget (Al-Mashari et al. 2003; Hong et al. 2002; Malbert et al. 2003).

5. System acceptance and usage (Ang et al. 1995; Ang et al. 2002; Yusuf et al. 2004).

6. Predetermined corporate goals (Al-Mashari et al. 2003; Umble et al. 2003; (Yusuf et al. 2004). 


\section{Methodology}

The research approach as a methodology was twofold; on one side we have based our research on original empirical researches, on the other side on literature review to complement our research. The extent of the search was not limited to scholarly journals, conference proceedings, doctoral theses, Web sites and textbooks.

Our aim was to carry out a qualitative, empirical research. To make available enough empirical data, we have grounded our investigation in BSC. / MSC. theses that were created on ERP at College of Dénes Gábor and Eötvös University (in Budapest, Hungary) as students' research project. In these projects, the fact finding and data gathering were conducted by prescribed methods. The theses that provided a part of empirical data and materials of indepth interviews are accessible and are available at request. In addition, there was an empirical research on the evolution of enterprise architecture of subsidiaries belonging to international companies and operating in Hungary (ELTE 2010). Beside companies situated in Hungary, the investigation covered the practice of ERP introduction at several German companies.

By its approach, case study paradigm as a research tool is well suited to the study of Information System (IS) implementation, especially when the contextual environment is important and the phenomenon is temporary (Miles and Huberman 1994). The case studies paradigm provides a sound basis for scientific generalization if it is correctly used.

\section{Case studies on the selection process of ERP systems in Hungarian and German companies}

\section{Phases of ERP introduction}

The samples in practice demonstrate that the introduction and application of ERP is a longstanding process. The selection of a proper solution is a several year project that can be divided up into stages. The required activities are planned and monitored till the introduction and operation by vendors so that they ensuring a successful project execution (Feuchtinger 2008). In this study we define five stages of introduction to take into account the practical experiences of case studies.

The companies frequently encounter a decision situation how they can modernize the existing data processing system. There are three different ways: development, package procurement and renting or leasing, i.e. paying fees on monthly or yearly base for the ERP services. In principle, open source ERP solutions can be considered as a reasonable alternative of development from scratch; the alignment of concrete solutions to the business needs can be carried out through a customization project. The rapidly proliferating Cloud Computation motivates the use of Open ERP solutions as a kind of renting or leasing. A developed system may comply with requirements and it can be tailor made for specific business processes; however it requires more resources (Ayağ and Özdemir 2007). Before the decision between the package solution and development, an analysis can be carried out. During the analysis the benefits and disadvantages of the package solution are assessed.

The third opportunity is renting or paying a fee for all or some services of an ERP system in the form of ASP, in the Cloud Computing as Software as a Service or as services some data centres. The financial resources for small and micro enterprises had not made a previous real option to procure an ERP system and to employ staff having skill in IT operation. The Open ERP systems may provide an opportunity to solve both the shortage of IT skill and business management. In the past years utilizing the opportunities in IT, there was a proliferation of systems that can be considered as Open ERP systems (Feilmeier 2012).

Most recently, the ASP (Application Service Providing) has been an appropriate, costeffective solution for micro and small enterprises. The services can be accessed through the Cloud Computing too. The Saas (Software as a Service) and Open ERP solutions seems financially and technically viable solutions for SMEs in Hungary. 


\section{Decision making about the introduction of an ERP solution}

The question emerges whether what the factors are that lead companies to consider replacing the operational legacy system fully or partially with a new information system. To find answers to the question we have investigated cases covering a wide spectrum and we have collected and highlighted justification from the projects executed to introduce ERP like systems.

A Hungarian Ltd. decided to adopt an ERP (ProFinance ${ }^{\mathrm{TM}}$ ) system, their justification contained three items having grounds in the underdeveloped, legacy information processing system. A company from the Netherlands had an AS/400 based system named TOTICS and had operated for 20 years. The new system is pre-condition to realize the business strategic plan; the new IS provides better reliability, higher service level for customers; to increase efficiency and to make more transparent to the business process within the business group; the system should support the business planning and consequently the cost-efficiency and serving the clients; the new IS creates the opportunity for an integrated system. (Tóth, 2008).

The subsidiary of a multinational oil company in Hungary used to employ JDE (J.D. Edwards) ERP system. The company decided to eliminate the heterogeneity of systems. The enterprises wanted one integrated solution. Considering the opportunities, the top management of multinational company made the decision for a project called Global SAP, GSAP project (Kulcsár 2008). The Dutch company settled to introduce SAP R/3 as well.

In one of our empirical research, we have met the following approach (ELTE 2010, Molnár and Szabó 2011): some business administration functions are centralized at some regional headquarters as e.g. invoice processing and payment. The SAP FI module is procured and customized to be dedicated to this task. Consequently, a business function is covered totally by a single ERP module introduced during the changeover.

In the above mentioned cases, the selection phase has been left out. The top management at both companies has made a strategic decision choosing an ERP system that is considered as best practice.

\section{Causes for Changeover}

As the before mentioned cases demonstrate, the base for a changeover of an ERP system consists of: (1) the requirement for information processing volume caused by the growth of business, acquiring a larger market share or the intention of it; (2) the necessity for modernization of legacy systems; (3) the requirement for company-wide integration, unification and creating uniformity in information processing.

However, there are issues to be considered before deciding on a changeover:

1. Whether are consultants needed although the system will be operated by the staff of the enterprise?

2. Whether the costs, the whole project budget can be planned in the selection phase? Some issues:

a. Fix cost at one-time investment, and variable cost at operation time;

b. Infrastructure investment and procurement;

c. Business efficiency and effectiveness of the new IT/IS solution;

d. Can be higher income for the enterprise anticipated?

e. Training and education for the employees and their costs includes maintaining the skill level.

f. Would the inventory management be improved?

3. Which are the business areas where cost savings can be achieved? Efficiency of production could decrease the costs of salaries and wages?

4. Whether should a safety deposit be established for financing the unexpected cost growth after ERP implementation?

\section{Objectives of ERP selection and practical approaches}

The difficulties in selection of ERP system did not originate from the fact that too few ERP systems are available on the market, in spite of it there are multitude of ERP systems. There are hundred vendors beside the major players in Germany (Grandjean, 2010). 
The primary vendor selection could be based on the market position within the specific ERP sector. (Meyer and Gronau, 2011). There are four factors that can be combined variably to represent the market position within competition in a Cartesian chart, namely the competitive advantage, financial soundness, technical knowledge and skill, the stability of business environment. The ERP system vendors can be shown in such a chart.

\section{Business Case}

One of the major objectives during the ERP selection is to mitigate the risks inherent in the selection process. In literature, there are lots of methods and models that have been widely discussed; two of them are outlined below.

When management considers several conflicting goals to be achieved, multi-criteria decision making (MCDM) models enable effective results in the ERP selection process. Subjective decision-making processes related to conflicting business problems with trade-off relationships may produce sub-optimal results. Appropriate ERP strategies must be established on a compromise-based and objective decision-making process among diverse stakeholders (Charnes and Cooper 1961), (Onut, Kara, and Isik, 2009).

Analytic Hierarchy Processing (AHP) is a generally used method for arranging goals, objectives in a hierarchical order. The basic aim of method is to support the decision making in a systematic manner using mathematical and computational procedures. The basic problems with both approaches is that the mathematical theory in background should be understood by top management and other stakeholders participating in the decision making process (Özdağoğlu and Özdağoğlu 2007). Both MCDM and AHP are discussed in literature, there are some case studies where the application of methods is demonstrated (Wei, Chien and Wang 2005), (Gunasekara, Ngai, and McGaughey 2006).

Besides the business and technical criteria and risks there are financial ones too. The financial perspective is based on cost savings and quantifiable implementation benefits. Evaluation methods include Net-Present-Value, Cost-Benefit Analysis, Payback, Return on Investment, etc. To assess the financial parameters one of the analysis models is the ROI (Return on Investment) that can be applied. (Lindemann, Schmid, and Gronau, 2007). TCO (Total Cost of Ownership) has been used in some cases as well.

There is an elaborated method that consists of several hundred questions. The in quiries address the efficiency of information processing taking into account the particularities of various industry sectors and size of enterprises. (Gronau, 2010).

\section{Soft Criteria for Selection}

Besides the service quality and financial criteria, there are lots of other objectives that should be taken into account during the selection process. The compliance to the requirements of the company is one of the most important criteria. To explore the discrepancies between the existing processes and the processes of potential ERP systems, a gap analysis should be performed.

The new ERP system may fulfil the recent requirements; however the ERP system should be prepared for future demands (Lotto, 2006). The stability of information systems means the adaptability to changes of technology, business processes and business environment so that anticipated feature of ERP system is certain degree stability.

The experiences show that if the set of functions is minimized for several reasons - financial, compliance, project timing, resources etc. - then later on, the enhancement and evolutionary development to react to the changing environment may cause extra costs and other operational difficulties in spite of the maximization of a collection of functions (Grandjean 2010). The flexibility of ERP systems is a success criterion within the corporate and SME world (Feuchtinger 2008).

The headquarters of multi-national corporations tend to centralize their management, control and governance systems to ensure an integrated and unified business administration. This tendency results in globalized ERP systems. (ELTE 2010), (Molnár et al. 2011). The concrete implementation is situated in the centralization-decentralization continuum both horizontally 
and vertically regarding the Zachmann architecture to provide the support that is required the top management of enterprises.

In selecting an EPR system to support globalized business activities, so-called country specific features should be taken into account. Such features include as follows: custom and excise handling; tax, revenue handling; commercial code; financial and cost accounting; banking, rules for bank accounts; local legal environment, jurisdiction. The required customization needs extra implementation effort generally. Some examples of the difficulties that occurred (Contini 2010): (1) Country specific, compulsory Chart of Account (Belgium); (2) accounting the transfer prices (Brazil); (3) handling and accounting the billing credit (Bulgaria); (4) country specific Payroll (Chile).

The described cases underpin the fact that during the selection process business-oriented criteria play an important role besides financial considerations.

\section{Discussion of case studies}

In this research we have investigated fourteen Hungarian companies, sixteen subsidiaries of multi-national companies operating in Hungary at a previous research (ELTE 2010), and five companies in Germany (PROZEUS 2010). The sources of seven furthermore case studies were business journals, white papers, technical and business reports. The fourteen case studies were elaborated by descriptive and analytical approach in BSc. and MSc. theses using primarily in-depth interviews and structured questionnaire that contained tentatively objectives for selection and introduction of ERP system (the theses may be available on request). The data and facts discovered in the various reports have been analysed and the cases show that criteria of financial, business, technical and market position play a role within the selection process of ERP systems. The criteria that are worth taking into account according to the case studies are as follows:

1. Current market position and long term sustainability and viability of market;

2. The alignment and/or the capability for adjustment of the potential ERP system to the specific industrial sector or business area,

3. The references of successful implementation;

4. Financial and business parameters of vendors;

5. The degree of dedication of rival enterprises to implementation and application of ERP solutions;

6. Interoperability, capability for integration to other legacy systems to be kept in operation;

7. The applied technologies for data management, software and information processing;

8. The support provided by the vendor at the introduction and operation of the system;

9. The costs and options for maintenance, upgrade, update and adaptation to the changing legal environment;

10. Language versions, localization opportunities in the case of multi-national, global companies;

11. Existence of country specific solutions in some business areas (e.g. Accounting);

12. IT networking capability of the ERP system to be adjusted to the recent state of the decentralization-centralization demand.

The case studies proved that the enterprises focus on the best practice of selection criteria. Relatively intricate financial modelling is applied for the reason that financial managers have a good knowledge on this topic.

The results of research can be summarized in a table. The assessment of each single factor (Table 1. and 2) is founded on analyzing the in-depth interviews, case studies, scientific, technical, business publications and other reports, overall 40 companies were involved in the research. We have analysed the frequency of occurrence of each single selection criterion in case studies and their exercised impacts on the final success of ERP systems. 
Table 1

Factors Influencing ERP Introduction and Implementation

\begin{tabular}{|l|l|l|l|l|l|l|l|}
\hline \multirow{2}{*}{$\begin{array}{l}\text { Factors' effect on ERP } \\
\text { implementation }\end{array}$} & $\begin{array}{l}\text { Weak } \\
\text { positive } \\
\text { impact }\end{array}$ & $\begin{array}{l}\text { Average } \\
\text { positive } \\
\text { impact }\end{array}$ & $\begin{array}{l}\text { Strong } \\
\text { positive } \\
\text { impact }\end{array}$ & Neutral & $\begin{array}{l}\text { Average } \\
\text { negative } \\
\text { impact }\end{array}$ & $\begin{array}{l}\text { Weak } \\
\text { negative } \\
\text { impact }\end{array}$ & $\begin{array}{l}\text { Strong } \\
\text { negative } \\
\text { impact }\end{array}$ \\
\hline $\begin{array}{l}\text { Top management } \\
\text { support }\end{array}$ & $24,24 \%$ & $15,15 \%$ & $18,18 \%$ & $18,18 \%$ & $6,06 \%$ & $9,09 \%$ & $9,09 \%$ \\
\hline $\begin{array}{l}\text { Company-wide } \\
\text { support }\end{array}$ & $24,2 \%$ & $15,2 \%$ & $12,1 \%$ & $12,1 \%$ & $12,1 \%$ & $12,1 \%$ & $12,1 \%$ \\
\hline $\begin{array}{l}\text { Business process } \\
\text { reengineering }\end{array}$ & $3,0 \%$ & $6,1 \%$ & $18,2 \%$ & $18,2 \%$ & $18,2 \%$ & $18,2 \%$ & $18,2 \%$ \\
\hline $\begin{array}{l}\text { Effective project } \\
\text { management }\end{array}$ & $21,2 \%$ & $21,2 \%$ & $21,2 \%$ & $9,1 \%$ & $9,1 \%$ & $9,1 \%$ & $9,1 \%$ \\
\hline $\begin{array}{l}\text { Organizational } \\
\text { culture }\end{array}$ & $3,0 \%$ & $6,1 \%$ & $12,1 \%$ & $12,1 \%$ & $27,3 \%$ & $18,2 \%$ & $21,2 \%$ \\
\hline $\begin{array}{l}\text { Education and } \\
\text { training }\end{array}$ & $6,1 \%$ & $21,2 \%$ & $36,4 \%$ & $9,1 \%$ & $9,1 \%$ & $9,1 \%$ & $9,1 \%$ \\
\hline User involvement & $3,0 \%$ & $6,1 \%$ & $18,2 \%$ & $18,2 \%$ & $18,2 \%$ & $18,2 \%$ & $18,2 \%$ \\
\hline User characteristics & $6,1 \%$ & $9,1 \%$ & $21,2 \%$ & $9,1 \%$ & $9,1 \%$ & $21,2 \%$ & $24,2 \%$ \\
\hline $\begin{array}{l}\text { ERP software's } \\
\text { suitability }\end{array}$ & $24,2 \%$ & $24,2 \%$ & $36,4 \%$ & $6,1 \%$ & $3,0 \%$ & $3,0 \%$ & $3,0 \%$ \\
\hline Information quality & $24,2 \%$ & $24,2 \%$ & $36,4 \%$ & $6,1 \%$ & $3,0 \%$ & $3,0 \%$ & $3,0 \%$ \\
\hline System quality & $24,2 \%$ & $24,2 \%$ & $36,4 \%$ & $6,1 \%$ & $3,0 \%$ & $3,0 \%$ & $3,0 \%$ \\
\hline ERP vendor quality & $6,1 \%$ & $24,2 \%$ & $36,4 \%$ & $21,2 \%$ & $3,0 \%$ & $6,1 \%$ & $3,0 \%$ \\
\hline
\end{tabular}

Source: Author's statistical analysis

The selection criteria that are described in scientific and technical literature were heterogeneously used by companies. We have established three categories to reflect the actual application of each single criterion (Table 2). The category for "Tentatively Considered" means that the criterion has been considered and informally used during the selection process, however for whatever reason, during the procurement and decision making the criterion has not been formalized and there was not any "exact" measurement process in place. In spite of this, the category of "Used in the Selection Process" means the formalization of the particular single criterion and the existence of subjective or objective measurement procedures. The explanation for category of „Not used” is self-evident.

The high level of information quality at the customer organization makes easier the introduction of an ERP system as the organization has been already accustomed to provide accurate, timely, reliable and consistent data.

The ERP vendors' quality emerges in the form of services that are provided by them during the ERP system implementation and the long-term operation as well. These services include response time of help desk; knowledgeable consultants having experiences in enterprise's business processes and information technology including vendor's ERP system. The participation and support of vendor's consultant in implementation and introduction is a significant factor. The services provided by consultants can be characterized by the level of knowledge in both customer's business processes and functions of the particular ERP system. The selection criteria that are described in scientific and technical literature were heterogeneously used by companies. We have established three categories to reflect the actual application of each single criterion (Table ). The category for "Considered" means that the criterion has been considered and informally used during the selection process, however for whatever reason, during the procurement and decision making the criterion has not been formalized and there was not any "exact" measurement process in place. In spite of this, the category of "Used" means formalization of the particular single criterion and the 
existence of subjective or objective measurement procedures. The explanation for category of "Not used" is self-evident.

Table 2

The selection criteria used in the process at the investigated companies

\begin{tabular}{|c|c|c|c|}
\hline Selection criteria & Used & Considered & Not used \\
\hline $\begin{array}{l}\text { Current market position and long term sustainability and } \\
\text { viability of market of ERP system; }\end{array}$ & $75 \%$ & $20 \%$ & $5 \%$ \\
\hline $\begin{array}{l}\text { The alignment and/or the capability for adjustment of } \\
\text { the potential ERP system to the specific industrial sector } \\
\text { or business area; }\end{array}$ & $88 \%$ & $8 \%$ & $5 \%$ \\
\hline Financial and business parameters of potential vendor; & $50 \%$ & $18 \%$ & $33 \%$ \\
\hline $\begin{array}{l}\text { The degree of dedication of rival enterprises to } \\
\text { implementation and application of ERP solutions; }\end{array}$ & $10 \%$ & $15 \%$ & $75 \%$ \\
\hline $\begin{array}{l}\text { Interoperability, capability for integration to other legacy } \\
\text { systems to be kept in operation; }\end{array}$ & $35 \%$ & $50 \%$ & $15 \%$ \\
\hline $\begin{array}{l}\text { The applied technologies for data management, } \\
\text { software and information processing; }\end{array}$ & $28 \%$ & $23 \%$ & $50 \%$ \\
\hline $\begin{array}{l}\text { The support provided by the vendor at the introduction } \\
\text { and operation of the system; }\end{array}$ & $78 \%$ & $23 \%$ & $0 \%$ \\
\hline $\begin{array}{l}\text { The costs and options for maintenance, upgrade, } \\
\text { update and adaptation to the changing legal } \\
\text { environment; }\end{array}$ & $75 \%$ & $20 \%$ & $5 \%$ \\
\hline $\begin{array}{l}\text { Language versions, localization opportunities in the case } \\
\text { of multi-national, global companies; }\end{array}$ & $43 \%$ & $33 \%$ & $25 \%$ \\
\hline $\begin{array}{l}\text { Existence of country specific solutions in some business } \\
\text { areas (e.g. Accounting); }\end{array}$ & $40 \%$ & $43 \%$ & $18 \%$ \\
\hline $\begin{array}{l}\text { IT-networking capability of the ERP system to be adjusted } \\
\text { to the recent state of the decentralization-centralization } \\
\text { demand. }\end{array}$ & $40 \%$ & $53 \%$ & $8 \%$ \\
\hline $\begin{array}{l}\text { The new system is pre-condition to realize the business } \\
\text { strategy plan; }\end{array}$ & $58 \%$ & $23 \%$ & $20 \%$ \\
\hline $\begin{array}{l}\text { The new IS provides better reliability, higher service level } \\
\text { for customers; }\end{array}$ & $10 \%$ & $58 \%$ & $33 \%$ \\
\hline $\begin{array}{l}\text { To increase efficiency and to make more transparent to } \\
\text { the business process within the business group ; }\end{array}$ & $70 \%$ & $20 \%$ & $10 \%$ \\
\hline $\begin{array}{l}\text { The system should support the business planning and } \\
\text { consequently the cost-efficiency; }\end{array}$ & $83 \%$ & $18 \%$ & $0 \%$ \\
\hline The system should provide support for serving the clients; & $48 \%$ & $45 \%$ & $8 \%$ \\
\hline IS creates the opportunity for an integrated system. & $83 \%$ & $13 \%$ & $5 \%$ \\
\hline
\end{tabular}

Source: Author's statistical analysis

The most critical step in the adoption of an ERP system is the selection process since the decision for selecting a particular ERP system influences long-term the efficiency and effectiveness as the service level of information system of the enterprise is determined by the new system in the future.

\section{Conclusion}

\section{Summary}

Our research aim was to examine the real-life selection processes for enterprises, the actually used criteria versus the proposed ones by scientific and business literature. As in all of the investigated cases the companies use their own ERP systems in practice every day, we have considered all projects in the phase of introduction or changeover as successful ones. 
The research highlights some discrepancies between the everyday practice and theory. Several methods that are proposed in scientific literature and by experiment seems feasible and useful, however they are not used in the case studies. The enterprises generally owns software tools (either commercial or open-source) that can provide the basic function to create more rigorous selection models as e.g. ANP/AHP based ones.

\section{Related Work}

The referenced research conclusion was that there is a high correlation between the companies' size (measured in the financial sense) and the planned and realized investment in ERP systems (Pacheco-Comer and González-Castolo 2012.

The AHP/ANP methods are discussed in the literature (Özdağoğlu et al. 2007; Wei et al. 2005; Gunasekaran et al. 2006), some applications of the method as case studies are described in scientific papers. This statement is valid for the multi-criteria decision making (MCDM) models as well (Charnes et al. 1961; Onut et al. 2009). Although in the articles, there is no report about the widespread application of the accurate and meticulous decision support methods, only some examples as case studies are demonstrated.

A research paper (Karsak and Özogul 2009) describes a decision making model using a combination of fuzzy regression, quality of the house and AHP. A decision support method based on fuzzy measure, Choquet integral and machine learning is presented in (Ariwa and El-Qawasmeh 2011); an illustrative example justifies the feasibility of the approach.

The use of AHP through a case study reported in a paper (Karaarslan and Gundogar 2009). A description of a multi criteria analysis method and its application for an industrial company is given in (Nikolaos, Sotiris, Harris and Nikolaos 2005). Again in a single case, the fuzzy AHP and the balanced scorecard method is combined (Cebeci 2009).

There is a research paper (Shakir 2000) that investigated other models for decision making and proposed models to be applied during the ERP project Lifecycle, however it does not contain empirical data on as whether how extensively the suggested decision making models are used actually, in real life projects.

Within an extensive empirical research - where 813 Austrian middle and large scale organizations had been surveyed (Bernroider and Koch 1999) - the result was similar to ours, namely the companies made use of standard financial evaluation methods.

The open source ERP and Open ERP solutions were not the subject of our investigation nor have we encountered in cases we have analyzed. There was research on open source ERP and their impacts on SMEs (Johansson and Sudzina 2008; Johansson and Sudzina 2009).

\section{Future Research Directions}

The future research should deal with the changing IT environment, especially the proliferation of Cloud Computing, the Software as a Service (SaaS), the application as a service, namely the ERP system services. In this situation, it will be worth investigating how the notion of ASP (Application Service Provider) changes and what the particular features may have regarding the ERP services. Similarly important phenomenon is the concept of Web services and its promise the flexible configuration and re-configuration of information system services along with the business processes.

These rapidly changing IT/IS environment enforces to raise the same research questions on issues of selection, introduction, adoption, customization and operation of the ERP service.

We have investigated criteria for selection of ERP systems in multiple case studies. We have encountered various viewpoints out of customer organizations and financial business models applied for evaluation. Another thread of investigation could be whether what computational intelligence and other computational models may be employed in the before-outlined changing environment that could flexible fit to the given situation and may provide useful information for the customer. 


\section{References}

1. Al-Mashari, M., Al-Mudimigh, A., Zairi, M., (2003), "Enterprise resource planning: taxonomy of critical factors", European, Journal of Operational Research Vol. 146 No. 2, pp. 352-364.

2. Ang, J.S.K., Sum, C.C., Chung, W.F., (1995), "Critical success factors in implementing MRP and government assistance", Information and Management Vol. 29. No.2, pp. 63-70.

3. Ang, J.S.K., Sum, C.C., Yeo, L.N., (2002), "A multiple-case design methodology for studying MRP success and CSFs", Information and Management Vol. 39. No. 4, pp. 271-281.

4. Ariwa, E., El-Qawasmeh, E., (2011), "A Learning Driven Model for ERP Software Selection Based on the Choquet Integral: Small and Medium Enterprises Context, Digital Enterprise and Information Systems", Communications in Computer and Information Science, No. 194, pp. 358-371.

5. Asl, M. B., Khalilzadehb, A., Youshanlouei, H. R., Moodd, M. M., (2012), "Identifying and ranking the effective factors on selecting Enterprise Resource Planning (ERP) system using the combined Delphi and Shannon Entropy approach", Procedia - Social and Behavioural Sciences Vol. 41, pp. $513-520$.

6. Ayağ, Z.; Özdemir, R. G. (2007), "An intelligent approach to ERP software selection through fuzzy ANP", International Journal of Production Research, Vol. 45. No. 10, pp. 2169-2194.

7. Bernroider, E.; Koch, S.; (1999), "Decision Making for ERP-Investments from the Perspective of Organizational Impact-Preliminary Results from an Empirical Study", Americas Conference on Information Systems, August 13 \pm 15 , Milwaukee, WI.

8. Bidgoli, Hossein, (2004). The Internet Encyclopedia, Volume 1, John Wiley \& Sons, Inc. 707.

9. Bingi, P., Sharma, M.K., Godla, J.K., (1999), "Critical issues affecting an ERP implementation", Information Systems Management Vol. 16, pp. 7-14.

10. Botta-Genoulaz V., Millet, P.-A., Grabot, B., (2005), A survey on the recent research literature on ERP systems, Computers in Industry, Vol. 56, pp. 510-522.

11. Cebeci, U., (2009), "Fuzzy AHP-based decision support system for selecting ERP systems in the textile industry by using balanced scorecard", Expert Systems with Applications, Vol. 36, No. 5, pp. 8900-8909.

12. Charnes, A., and Cooper, W. W., (1961), Management models and the industrial applications of linear programming, Vols. 1-2. Wiley: New York.

13. Contini, L. (2010), „Einfluss nationaler Charakteristika in internationalen Projekten zur Einführung von ERP Systemen" [Influences of country-specific features on projects for implementation of ERP systems], Unpublished PhD, Universität Passau, available at: http://www.opus-bayern.de/unipassau/volltexte/2011/2249/pdf/Contini_Nemmert_Luisa.pdf / (January, 2012)

14. Eggert, S., Fohrholz, C., (2009). "Marktrecherche zum Thema ERP-Internationalisierung“, ERP Management 1/2009, pp. 52-61.

15. ELTE (Research Group at Eötvös University in Budapest) (2010). Research report about the effect of globalization on ERP Systems and their deployment structure at local companies of international enterprises (in Hungarian ), The Evolution of Enterprise Architecture, Eotvos University of Budapest (ELTE) Retrieved 15 June 2010 from http://www.mtaita.hu/hu/Publikaciok/ERP_Kutatasi_Beszamolo_2010_05_10_.pdf.

16. Esteves, J., Bohórquez, V. W., (2007) An Updated ERP Systems Annotated Bibliography: 2001-2005 (March 21, 2007). Instituto de Empresa Business School Working Paper No. WP 07-04.

17. Feilmeier, S., (2012), „Evaluation und Implementierung des Open Source ERP-Systems 'OpenERP' in einem Start-Up-Unternehmen", [Evaluation and implementation of the open source ERP system "OpenERP" in a startup company], BsC. Thesis, Bachelorarbeit zur Erlangung des akademischen Grades an der Hochschule Deggendorf.

18. Feuchtinger, H., (2008), „ERP Auswahl und Einführung“, ERP Management, 12/2008, pp. 17-19.

19. Grandjean, W. (2010), „Die 10 Gebote der ERP-Auswahl“, ERP Management, 6/2010, pp. 59-60. 
20. Gronau, N. (2007), ERP-Lösungen erschließen neve Märkte. ERP Management, 08/2007, pp. 16-18.

21. Gronau, N. (2007a), Enterprise Resource Planning und Supply Chain Management: Architektur und Funktionen, [Enterprise Resource Planning and Supply Chain Management: Architecture and Functions], Berlin: Oldenbourg Wissensch.

22. Gronau, N. (2010), „ERP-Auswahl mittels Rol-Analyse-Risikoreduzierung und Nutzensteigerung", ERP Management, 6/2010, pp. 18-20.

23. Gunasekaran, A. , Ngai, E.W.T., McGaughey, R.E. (2006), "Information technology and systems justification: A review for research and applications", European Journal of Operational Research, Vol. 173, No. 3, pp. 957-983.

24. Hong, K.K., Kim, Y.G., (2002). "The critical success factors for ERP implementation: An organizational fit perspective", Information and Management Vol. 40, pp. 25-40.

25. Ifinedo, P., Rapp, B., Ifinedo, A., Sundberg, K., (2010) "Relationships among ERP postimplementation success constructs: An analysis at the organizational level", Computers in Human Behavior, Vol. 26, No. 5, pp. 1136-1148.

26. Jacobs, F. R., Weston, F.C., (2007), "Enterprise resource planning (ERP)—A brief history", Journal of Operations Management, Vol. 25, pp. 357-363.

27. Jacobs, F. R., Whybark, D. C., (2000), Why ERP? A Primer on SAP Implementation. New York: Irwin McGraw-Hill.

28. Johansson, B. Sudzina, F., (2008), "ERP systems and open source: an initial review and some implications for SMEs", Journal of Enterprise Information Management, Vol. 21. No. 6., pp. 649-658.

29. Johansson, B. Sudzina, F., (2009), "Choosing Open Source ERP Systems: What Reasons Are There For Doing So?, Open Source Ecosystems: Diverse Communities Interacting", IFIP Advances in Information and Communication Technology, pp. 143-155.

30. Karaarslan, N., Gundogar, E., (2009), "An application for modular capability-based ERP software selection using AHP method", The International Journal of Advanced Manufacturing Technology, Vol. 42, No. 9-10, pp. 1025-1033.

31. Karsak, E. E., Özogul, C. O., (2009), "An integrated decision making approach for ERP system selection", Expert Systems with Applications, Vol. 36,No.1, pp. 660-667.

32. Kulcsár L., (2008), GSAP project at Shell Hungary Plc. and the requirements for infrastructure, Unpublished BSc thesis at College of Dénes Gábor, [(Kulcsár L., (Kulcsár 2008). GSAP project a Shell Hungary Rt-nél és annak infrastruktúra vonzata. (GDF azon: 623/2006)I.]

33. Lassmann, W. (Hrsg.), Wirtschaftsinformatik Nachschlagewerk für Studium und Praxis, Betriebswirtschaftlicher Verlag Dr. Th. Gabler, GWV Fachverlage GmbH, Wiesbaden.

34. Liao, X., Li, Y., \& LU, B.( 2007), "A model for selecting an ERP system based on linguistic information processing", Information Systems, Vol. 32, No.7, pp. 1005-1017.

35. Lindemann, M.; Schmid, S.; Gronau, N. (2007), "Wirtschaftlichkeitsbewertung der Einführung von Manufacturing Execution Systems". [Financial Analysis for Implementation of Manufacturing Execution Systems] VDMA Nachrichten; 02/2007, pp. 60-61.

36. Lotto P. (2006), „Befriending your ERP system“, Electrical Wholesaling, Vol. 87, No. 11, pp. 54-56.

37. Malbert, V.A., Soni, A., Venkataramanan, M.A., (2003), "Enterprise resource planning: Managing the implementation process", European Journal of Operational Research Vol.146 No. 2, pp. 302-314.

38. Mandal, P., Gunasekaran, A., (2002), "Application of SAP R/3 in on-line inventory control, International Journal of Production Economics", Vol. 75, No. 1-2, pp. 47-55.

39. Mark, A., Rajiv, B., Nirup, M., Jorge, R., (2011), "Implementing enterprise resource planning systems: organizational performance and the duration of the implementation", Information Technology and Management, Vol. 12, No 3, pp. 197-212.

40. Meyer, J., Gronau, N., (2011), "Nutzung der Branchenstärke in der ERP-Auswahl“" [Exploitation of strengthening of sector in dire Selection Process For ERP]. ERP Management, 7/2011, pp. 48-50. 
41. Miles, M.B., Huberman, A.M., (1994), Qualitative Data Analysis: An Expanded Sourcebook. London: Sage, Thousand Oaks.

42. Molnár, B., (2011), "The country specific organizational and information architecture of ERP systems at globalised enterprises", Business Systems Research Journal, Vol. 2, No. 2, pp. 39-50.

43. Molnár, B., Szabó, Gy. (2011), "Information Architecture of ERP Systems at Globalised Enterprises in a Small EU Member State", Proceedings of the ITI 2011 33rd, International Conference on Information Technology Interfaces, June 27-30, 201 1, Cavtat, Croatia.

44. Nazemi, E., Tarokh, M. J., Djavanshir, G. R., (2012), "ERP: a literature survey", International Journal of Advanced Manufacturing Technologies, Vol. 61, No. 9-12, pp. 999-1018.

45. Nikolaos, P., Sotiris, G., Harris, D., Nikolaos, V., (2005). "An application of multicriteria analysis for ERP software selection in a Greek industrial company", Operational Research, Vol. 5, No. 3, pp. 435-458.

46. Onut, S., Kara, S. S., Isik, E. (2009), "Long term supplier selection using a combined fuzzy MCDM approach: A case study for a telecommunication company", Expert Systemswith Application, Vol. 36, No. 2, pp. 3887-3895.

47. Özdağoğlu, A., Özdağoğlu, G. (2007), "Comparison of AHP and fuzzy AHP for The multicriteria decision making processes with linguistic evaluation", Istanbul Ticaret Üniversitesi Fen Bilimleri Dergisi Yıl 6 Sayı:11Bahar 2007/1 s. 65-85, available at http://www.iticu.edu.tr/yayin/dergi/f1 1/M00178.pdf /January, 2012

48. Pacheco-Comer, A. A., González-Castolo, J. C., (2012), "An empirical study in selecting Enterprise Resource Planning Systems: The relation between some of the variables involve on it. Size and Investment", Procedia Technology, Vol. 3, pp. 292-303.

49. PROZEUS (2010). eBusiness-Standards in der Praxis: Stammdatemanagement und ERPEinführung in kleinen und mittleren Unternehmen. [eBusiness-Standards in Practice: Master Data Management and Implementation of ERP within SMES], available at http://www.prozeus.de/imperia/md/content/prozeus/broschueren/pro_brochure_ebusin ess_standards_neu.pdf / (January, 2012).

50. Shakir, M., (2000) "Decision Making in the Evaluation, Selection and Implementation of ERP Systems", AMCIS 2000 Proceedings. Paper 93, available at http://aisel.aisnet.org/amcis2000/93 / (January, 2012).

51. Siegel, J. G., Shim, J. K., (2005), Dictionary of Accounting Terms, Woodbury: Barron's Educational Series.

52. Umble, E.J., Haft, R.R., Umble, M.M., (2003), "Enterprise resource planning: Implementation procedures and critical success factors", European Journal of Operational Research Vol. 146, No. 2, pp. 241-257.

53. Wei, C.-C. , Chien, C.-F. Wang, M.-J. J. (2005), "An AHP-based approach to ERP system selection", International Journal of Production Economics, Vol. 96, No. 1, pp. 47-62.

54. Wei, C.-C., Wang, M.-J. J., (2004), "A comprehensive framework for selecting an ERP system", International Journal of Project Management, Vol. 22, No.2, pp. 161-169.

55. Yen D. C., Chang C. J., (2002), "A synergic analysis for Web-based enterprise resources planning systems", Computer Standards \& Interfaces, Vol. 24, No. 4, pp. 337-346.

56. Yusuf, Y., Gunasekaran, A., Abthorpe, M.K., (2004), "Enterprise information systems project implementation: A case study of ERP in Rolls-Royce", International Journal of Production Economics, Vol. 87, No. 3, pp. 251-266. 


\section{About the authors}

Bálint Molnár, Senior Researcher at Eötvös University of Budapest, he teaches: Methodologies of Information System Development, ERP and Integrated Systems, Web technologies for Enterprise Information Systems. He is Associate Professor at Corvinus University of Economic Sciences and Public Administration, he teaches: Development of Information Systems, Project management, Knowledge-based systems development. His research area: Information System Modelling, ERP systems, Business Process Modelling, Semantic Web, Enterprise Architectures, SOA, Data mining and Business Intelligence. He is a member of the editorial board of Journal of Information Technology \& Politics, The Electronic Journal of Knowledge Management (EJKM), Singidunum Journal of Applied Sciences. Author can be reached at molnarba@inf.elte.hu

Gyula Szabó Professor at "Dennis Gabor" University Applied Sciences of Budapest, he teaches: Methodologies of Information System Development, ERP and Integrated Systems, Enterprise Architectures. He is Associate Professor at Eotvos University of Budapest, he teaches: Enterprise and Industrial Information Systems. His research interest covers topics that were before-mentioned as teaching subjects. He has published several scientific and professional papers. He is a member of the Hungarian Humboldt Association. Author can be reached at bpinformatik@gmail.com

András Benczúr, Sciences at the Hungarian Academy of Sciences. He teaches database technology, information theory. His research interest covers database management systems, information systems theory, information systems technology, algorithmic information theory, grid, and cloud technology. Author can be reached at abenczur@inf.elte.hu 